\title{
(Re)Conceptualizing Families: An Introduction
}

\author{
Jennifer Haskin* \\ Arizona State University
}

*Please address all correspondence to Jennifer Haskin, PhD, Barrett Honors

Faculty, T. Denny Sanford School of Social and Family Dynamics, Arizona State

University, P.O. Box 873701, Tempe, AZ 85287-3701. E-mail:

jhaskin5@asu.edu.

The aim of this special issue of Michigan Family Review, "(Re) Conceptualizing "Family," is to highlight scholarly work that challenges the prevailing ideologies of the "traditional family" that center on a white, middle class, heterosexual breadwinner/homemaker framework. In fact, less than half of today's children in the Unites States are living in a family with two married parents (Pew Research Center, 2015). There is no question that today's families take on a wide variety of arrangements; most of which do not resemble the "traditional family" model. Each of the articles featured in this volume highlight the varied forms that contemporary families take, explore some of the issues they face, and encourage us all to (re)conceptualize "family."

In the first article, “"My Wife's Pregnant, We're Gonna Have a Baby!” "Oh, Tell Her Congratulations!” Same-Sex Couples Desire for Support in Parenting," Allison Jendry James describes some of the challenges that same sex couples face in raising children. Central themes in this piece include legal challenges (i.e. power of attorney, parenting rights), as well as challenges related to parenting (i.e. acceptance, religious values, prioritizing family time, parental roles). Findings from this research suggest that despite the legalization of same sex marriage in the US, same sex families are not getting the support they need from broader society.

Cherise Harris and Kristie Ford bring awareness to how explore intersectionality in black single mothers by choice in “'Where's your Man?': Intersectionality in the Adoption Stories of Two Black, Single Female Sociologists." Specifically, the authors aim to explore some of the emotional challenges of adoption, examine how some families are devalued in the United States, and raise awareness to the ways in which the adoption process is raced, classed, and gendered. 
In “'Steps to our Culture': Cultural Cultivation and Teaching Children about a Culture 'Left Behind,'” Pangri Mehta examines how Indian immigrant families engage in ethnic and cultural socialization practices through "cultural cultivation" at a Bollywood dance studio. Cultural cultivation for the families in this study is a highly valued and deliberate practice. It also provides a sense of community, and cultural competence for immigrant parents (particularly immigrant mothers) and their children.

The final article by Kara Takasaki, titled, "Friends and Family in Relationship Communities: The Importance of Friendship during the Transition to Adulthood," explores how emerging adults who have delayed forming families of their own through marriage and childbearing form adult identities. Building on a personal communities' framework (Spencer \& Pahl, 2006) and an understanding of culture as a "tool kit" that informs strategies of action (Swidler, 2001), Takasaki finds class based differences in the personal communities, and kinds of friendships emerging adults have.

Families are dynamic, and the varied forms they take are reflective of social and structural conditions. Coincidentally, the challenges diverse families face tends to reflect the lack of social, political, and economic supports and resources. The four articles in this volume help explain some of the challenges faced by contemporary families, and call our attention to the need for research on the experiences of contemporary families.

\section{References}

Pew Research Center. (December 17, 2015). Parenting in America: Outlook, worries, aspirations are strongly linked to financial situation. The American family today. Retrieved from http://www.pewsocialtrends.org/2015/12/17/1-the-american-family-today/

Spencer, L., \& Pahl, R. (2006). Rethinking friendship: Hidden solidarities today. Princeton, NJ: Princeton University Press.

Swidler, A. (2001). Talk of love: How culture matters. Chicago, IL: The University of Chicago Press. 